\title{
Feeding habits of pandalid shrimps in the Alboran Sea (SW Mediterranean): influence of biological and environmental factors
}

\author{
Emanuela Fanelli* ${ }^{*}$ Joan E. Cartes \\ Institut de Ciéncies del Mar, Passeig Maritim de la Barceloneta 37-49, 08003 Barcelona, Spain
}

\begin{abstract}
The feeding habits of 4 species of Plesionika inhabiting the Alboran Sea (SW Mediterranean) at depths between 29 and $790 \mathrm{~m}$ were analyzed. Included within the trophic guild of nonmigratory macroplankton feeders, Plesionika spp. preferably exploited mesopelagic resources (mainly euphausiids and Myctophidae). Deep-bathyal species (P. martia, P. gigliolii and P. edwardsi) fitted better within this guild, while the shallower living species $P$. heterocarpus, which inhabits the shelf-slope break, consumed benthic organisms (e.g. polychaetes, bivalves and tanaids). In a multispecies MDS analysis, diets of $P$. martia and P. heterocarpus were grouped as a function of depth. Latitude, phytoplankton pigment (PP) concentration recorded 4 wk before the sampling date (PP4) and depth were the explanatory variables of stomach fullness of Plesionika (all species: $\mathrm{R}^{2}=0.674$ in a multiple linear regression model, MLR). The abundance of $P$. martia also showed a positive significant correlation (Spearman r) with PP4. Possible causes of higher shrimp aggregations in P. martia could be related to reproductive processes because peaks of mature females were reported at similar periods in neighboring areas. In both dominant Plesionika species ( $P$. martia and $P$. heterocarpus), MDS dimensions for diets were also correlated with PP4, although significant correlations with other PP data taken at different periods (from simultaneous PP data to PP6, 6 wk before sampling) were also found. These trends suggest that macroplankton-feeder Pandalidae may couple some aspects of their biology with blooms of plankton and ultimately with peaks of primary production. Prey size selection occurred among Plesionika spp., which suggested a hunting activity. Correlations between Plesionika spp. size $(C L, \mathrm{~mm})$ and prey size were positive, both for fish $\left(\mathrm{R}^{2}=0.437\right)$ and for euphausiids $\left(\mathrm{R}^{2}=0.440\right)$. Otolith length (mainly of Benthosema glaciale) and the size of euphausiid mandibles (Meganyctiphanes norvegica and Euphausia hemigibba) increased with predator size. Further evidence of active predation by deep pandalids, for example changes in the daily feeding activity of species, were evidenced for $P$. martia with higher foregut fullness at the beginning of the daytime period (from 06:00 to 08:00 $\mathrm{h}$ ) related to predation on euphausiids.
\end{abstract}

KEY WORDS: Pandalid shrimps $\cdot$ Diet $\cdot$ Feeding guilds $\cdot$ Primary production

\section{INTRODUCTION}

Decapod crustaceans are a dominant taxon at slope depths in tropical and subtropical regions, the case of the deep Mediterranean (Cartes 1993c), with an important contribution to the energy flow among the highest trophic levels. Thus, in a preliminary energy balance study performed in the Catalan Sea, food consumption deduced for decapods was similar to that cal- culated for fish (Cartes \& Maynou 1998). Pandalids are one of the most characteristic and diversified families of marine shrimps. The genus Plesionika (Decapoda, Caridea) is widely distributed in tropical and subtropical areas (Zariquey Alvarez 1968, Crosnier \& Forest 1973). P. heterocarpus (Costa, 1871) is abundant in the mud assemblage of the shelf-slope break and the upper slope of the Alboran Sea (SW Mediterranean), while P. gigliolii (Senna, 1903), P. edwardsii (Brandt, 
1851) and P. martia (A. Milne Edwards, 1883) are dominant in bathyal communities of the upper and middle slope. The Alboran Sea is characterized by the dominance of pandalid shrimps, which reach the highest values of abundance along the Iberian coasts. There is a tendency to shallower distribution of Plesionika spp. in the Alboran Sea compared with other study areas (Carbonell \& Abelló 1998). P. heterocarpus is distributed in the Alboran Sea from 47 to 467 m, with a bimodal distribution and the highest abundance between 100 and $150 \mathrm{~m}$, and 200 and $300 \mathrm{~m}$ depth. $P$. edwardsii occurs from 300 to $400 \mathrm{~m}$, always with very irregular and rather low densities. P. gigliolii is distributed from 248 to $600 \mathrm{~m}$ with peaks of abundance between 300 to $500 \mathrm{~m}$, whereas P. martia was found almost exclusively on the middle slope of the Alboran Sea from 300 to 800 m (Carbonell \& Abelló 1998). Similar distributions and patterns of species substitution with depth were found in neighboring areas (Cartes et al. 1993, Maynou \& Cartes 2000).

The trophic habits of some pandalid shrimps were reported by Lagardère $(1972,1977)$, Wienberg (1980), Cartes (1993a,b, 1998) and Mura (1995). Plesionika species mainly exploit benthopelagic resources, preying on euphausiids and mesopelagic decapods (e.g. Pasiphaea spp. and Sergestidae). They can be included in a trophic guild (Cartes 1998, Cartes et al. 2002), with only some species exploiting other compartments (e.g. P. heterocarpus, which also consumes infauna, particularly polychaetes in the Bay of Biscay, Lagardère 1977). Scavenging on fish remains were also reported, particularly in areas where the species is not dominant (e.g. the case of P. martia) at the limit of its geographical distribution (Lagardère 1977). Size segregation by coexisting Plesionika species having the same trophic guild has also been indicated in a previous study performed in the Catalan Sea (Cartes 1994).

Although changes in temperature and phytoplankton concentration have been related to the diversity of fish communities (McClatchie et al. 1997, Jacob et al. 1998), such variables have been rarely considered at the autoecological level (Cartes et al. 2004). Most feeding/dietary studies, therefore, lack an analysis of factors influencing feeding activity (e.g. stomach fullness, daily rations) and diet, which include prey/food availability as well as spatio-temporal short-scale changes in productivity and oceanographic conditions. Beyond the description of the diets and feeding habits of the 4 pandalid species occurring in the Alboran Sea, the objective of this study was to analyze the possible influence of environmental and biological factors in the feeding and diet of Plesionika species. Physical (e.g. temperature and salinity), trophic (e.g. phytoplankton concentration and prey availability) and bio- logical variables (e.g. sexual state, and density) were considered.

\section{MATERIALS AND METHODS}

During cruise MEDITS-ES02 (11 to 17 May 2002), 27 hauls were carried out between depths of 29 and $790 \mathrm{~m}$ along the coasts of the Alboran Sea (SW Mediterranean) from the Strait of Gibraltar (ca. $36^{\circ} 00^{\prime} \mathrm{N}$, $\left.5^{\circ} 50^{\prime} \mathrm{W}\right)$ to the Cape of Gata $\left(36^{\circ} 38^{\prime} \mathrm{N}, 2^{\circ} 05^{\prime} \mathrm{W}\right)$, over a spatial scale of ca. $300 \mathrm{~km}$. Plesionika shrimps were collected from trawl hauls between 69 and $715 \mathrm{~m}$. Shrimps were sampled with a bottom trawl (Bertrand et al. 2000). The horizontal aperture of the gear was ca. $18 \mathrm{~m}$ and the vertical opening was ca. $2 \mathrm{~m}$. The codend mesh size was $10 \mathrm{~mm}$. Haul duration was $0.5 \mathrm{~h}$ at depths $<200 \mathrm{~m}$ and $1 \mathrm{~h}$ at greater depths.

Abundance and biomass were calculated ( $\mathrm{N}$ ind. $\mathrm{km}^{-2}$ ) after standardizing catches to swept area $\left(\mathrm{km}^{2}\right)$. Distance and mouth trawl width were recorded using a SCANMAR system attached to the trawl for each haul.

A total of 240 specimens of Plesionika heterocarpus, 71 of $P$. gigliolii, 21 of $P$. edwardsii and 231 of $P$. martia were studied to establish the foregut fullness for each species (see Table 1). Individuals were measured (carapace length, $C L$, in $\mathrm{mm}$ with an accuracy of $0.1 \mathrm{~mm}$ ) dorsally from the posterior edge of the eye socket to the posterior edge of the cephalothorax using a vernier caliper and weighed to the nearest $0.1 \mathrm{~g}$. Information on gonadal development and ovigerous females was also collected. The wet weight of stomach contents was measured. Prey in stomach contents were ascribed in the laboratory under a stereomicroscope (10 to $40 \times$ ) to the lowest possible taxonomic level.

The following indexes were calculated (see Hyslop 1980 for a review): (1) percentage of vacuity (empty stomachs / total stomachs $\times 100$ ), (2) stomach fullness (stomach weight / shrimp weight $\times 100$ ), (3) frequency of occurrence $(\% F)$ of prey, (4) percentage of numeric abundance of prey $(\% N)$ and (5) percentage of wet weight of prey $(\% W)$. The percentage of volume of stomach contents was estimated using the subjective points methods (Swynnerton \& Worthington 1940) for the different prey-species or prey-groups.

Trophic diversity was calculated on the diet of each species using the Shannon-Wiener index, $H^{\prime}$ (Shannon $\&$ Weaver 1949), species richness, $d$ (Margalef 1958) and the evenness index, $J^{\prime}$ (Pielou 1966).

General affinities between the samples (diets) were established using multivariate cluster analysis (cf. Cartes \& Abelló 1992) for Plesionika martia and $P$. heterocarpus, after a log-transformation of matrix data, based on prey weight for each haul. Cluster analysis, using UPGMA (Pielou 1984) as the algorithm 
of aggregation and $1-r$ (the linear correlation of Pearson) as the distance, was used to classify the samples. On the basis of the similarity matrix generated, Multidimensional Scaling (MDS) techniques were applied for the ordination of samples (as a function of their prey composition) along 2-dimensional axes.

We also calculated Spearman's correlation coefficients between fullness and the projections of diet per haul along dimensions 1 and 2 of MDS. The variables were: (1) hour of sampling, depth, latitude and longitude; (2) oceanographic data (water temperature on the bottom and salinity); (3) trophic variables: phytoplankton pigment concentration recorded simultaneously to sampling date $\left(\mathrm{PP}_{\text {sim }}\right)$ and 1 (PP1), 2 (PP2), 3 (PP3), 4 (PP4) and 6 (PP6) weeks before the sampling date; abundance of euphausiids, natantian decapods, calanoids and suprabenthos (including mysids, isopods and amphipods) as the main available food resources; and trophic diversity $\left(H^{\prime}\right.$ : Shannon-Wiener index); and (4) biological features of the shrimps: percentage of ovigerous shrimps, percentage of mature females, mean weight of Plesionika species, mean weight of prey and density of the species. All of the above variables were tested as possible explanatory variables of feeding (fullness) and dietary patterns deduced from MDS analysis.

A multiple linear regression model (MLR) relating fullness to environmental variables (hour of sampling, depth, latitude and longitude; oceanographic data; and trophic variables) was established by forward stepwise multiple regression using the complete data set (all species: 23 cases). All MLR models were generated using the software Statistica 6.0. Biological variables were not considered in this analysis due to the restricted period of our sampling.

Data of primary production at time of sampling and at different time intervals later were obtained from www.ieo.es and seawifs.gsfc.nasa.gov, which provide daily to weekly, and monthly average values for surface temperature and phytoplankton pigment concentration (PP). Maps of temperature corresponded to May 2002. Maps of PP were obtained weekly from mid March to early June to test possible relationships between feeding intensity and surface PP. Different periods, both at the time of sampling and before $(2 \mathrm{wk}$, $1 \mathrm{mo}$ and $2 \mathrm{mo}$ ) were considered. Satellite images were downloaded and the scale of PP values was superimposed on each image (Photoshop 6.0) on the position of trawls to obtain the corresponding readings of PP, always before getting the rest of the variables. The abundances of euphausiids and natantian decapod shrimps, calanoids and suprabenthos were obtained with a zooplankton net (mouth aperture $40 \times 60 \mathrm{~cm}$, mesh size $0.5 \mathrm{~mm}$ ) attached to the upper part of the trawl at ca. $2 \mathrm{~m}$ from the bottom.
Relationships between the size of predators (Plesionika spp.) and their prey were also examined. Pandalid prey are usually broken in the stomach; therefore, we considered maximum otolith length for fish (myctophids, mainly Benthosema glaciale) and mandible height for euphausiids (chiefly Euphausia hemigibba and Meganyctiphanes norvegica). Both measurements were taken with an ocular scale on a stereomicroscope.

\section{RESULTS}

\section{Abundance}

The distributions of the abundances of Plesionika spp. are shown in Table 1. P. heterocarpus was the most abundant species in this study, both in terms of biomass and density; it reached more than 200 ind. $\mathrm{km}^{-2}$ in the eastern part of the area. P. gigliolii was more abundant than $P$. martia, whereas $P$. martia showed a higher biomass (mean value $=0.008 \mathrm{~kg} \mathrm{~km}^{-2}$ ).

\section{Diet composition}

\section{Plesionika heterocarpus}

The diet of this species was highly diverse (Table 2): sponges, polychaetes (mainly Eunicidae), euphausiids, mysids (Boreomysis spp., Leptomysis sp. and Siriella norvegica), hyperiids, isopods (mainly Cirolanidae), tanaidaceans, copepods (calanoids and harpacticoids), insect remains (e.g. Diptera), gastropods (Rissoa sp. and Benthonella sp.), bivalves (Lucinidae and Chlamys sp.), benthic and mesopelagic fish, and benthic and planktonic foraminiferans. The frequency of prey occurrence combined with weight and number is shown in Fig. 1. Most of the diet consisted of euphausiids (Euphausia hemigibba) and mysids, while bivalves and fish remains were also important prey. Polychaetes, hyperiids and tanaidaceans (Apseudes spp.) were a secondary food source. Diversity indexes for Plesionika heterocarpus (Table 3) showed the highest values compared to the other 3 species, though diversity within the same species demonstrated no differences among the hauls.

A significant correlation of fullness by sample was found with latitude (Spearman r: 0.783, p < 0.012) and longitude ( $\mathrm{r}:-0.683, \mathrm{p}<0.042$ ), while a highly significant correlation was found with PP4 (r: 0.950, $\mathrm{p}<10^{-5}$ ) and trophic diversity ( $\mathrm{r}: 0.750, \mathrm{p}<0.019)$. No pattern in diet composition was found with MDS analysis, but correlations with the projections of samples in dimensions 1 and 2 of MDS $(n=9)$ showed a significant cor- 
Table 1. Plesionika species. Sampling data and abundance $\left(\mathrm{N} \mathrm{ha}^{-1}\right)$ in the present study

\begin{tabular}{|c|c|c|c|c|c|c|}
\hline \multirow[t]{2}{*}{ Date } & \multirow[t]{2}{*}{ Location } & \multirow{2}{*}{$\begin{array}{l}\text { Depth } \\
\text { (m) }\end{array}$} & \multicolumn{4}{|c|}{ Number of individuals } \\
\hline & & & P. heterocarpus & P. gigliolii & P. martia & P. edwardsii \\
\hline 11 May 02 & $36.618 \mathrm{~N} ; 4.426 \mathrm{E}$ & $69-70$ & 23.587 & & & \\
\hline 11 May 02 & $36.570 \mathrm{~N} ; 4.352 \mathrm{E}$ & $194-205$ & 8.724 & & & \\
\hline 11 May 02 & $36.604 \mathrm{~N}_{;} 4.324 \mathrm{E}$ & $166-173$ & & & & \\
\hline 12 May 02 & $36.690 \mathrm{~N}_{;} 4.274 \mathrm{E}$ & $45-43$ & & & & \\
\hline 12 May 02 & $36.640 \mathrm{~N}_{;} 4.056 \mathrm{E}$ & $272-275$ & 52.374 & 0.235 & & \\
\hline 12 May 02 & $36.622 \mathrm{~N} ; 4.054 \mathrm{E}$ & $330-330$ & 1.462 & 0.700 & & \\
\hline 12 May 02 & $36.508 \mathrm{~N} ; 4.157 \mathrm{E}$ & $525-534$ & & & 0.755 & \\
\hline 13 May 02 & $36.557 \mathrm{~N} ; 4.508 \mathrm{E}$ & $71-77$ & 30.096 & & & \\
\hline 13 May 02 & $36.471 \mathrm{~N} ; 4.557 \mathrm{E}$ & $100-141$ & & & & \\
\hline 14 May 02 & $36.350 \mathrm{~N} ; 5.205 \mathrm{E}$ & $52-34$ & & & & \\
\hline 14 May 02 & $36.308 \mathrm{~N}_{;} 5.157 \mathrm{E}$ & $119-128$ & 0.481 & & & \\
\hline 14 May 02 & $36.286 \mathrm{~N} ; 5.059 \mathrm{E}$ & $357-350$ & 3.323 & & & \\
\hline 14 May 02 & $36.237 \mathrm{~N}_{;} 4.983 \mathrm{E}$ & $633-668$ & & & 0.648 & \\
\hline 14 May 02 & $36.239 \mathrm{~N}_{;} 4.921 \mathrm{E}$ & $701-722$ & & & 0.721 & \\
\hline 15 May 02 & $36.356 \mathrm{~N} ; 4.687 \mathrm{E}$ & $576-536$ & & & 1.502 & \\
\hline 15 May 02 & $36.322 \mathrm{~N}_{;} 4.429 \mathrm{E}$ & $765-755$ & & & 0.257 & \\
\hline 15 May 02 & $36.335 \mathrm{~N} ; 4.285 \mathrm{E}$ & $721-709$ & & & 1.280 & \\
\hline 15 May 02 & $36.440 \mathrm{~N} ; 4.170 \mathrm{E}$ & $623-598$ & & & 0.544 & \\
\hline 16 May 02 & $36.601 \mathrm{~N} ; 3.875 \mathrm{E}$ & $562-546$ & & & 1.288 & \\
\hline 16 May 02 & $36.652 \mathrm{~N} ; 3.823 \mathrm{E}$ & $342-320$ & & 1.917 & & \\
\hline 16 May 02 & $36.703 \mathrm{~N}_{;} 3.576 \mathrm{E}$ & $67-68$ & & & & \\
\hline 16 May 02 & $36.676 \mathrm{~N} ; 3.271 \mathrm{E}$ & $371-386$ & & 2.401 & & 1.982 \\
\hline 16 May 02 & $36.657 \mathrm{~N}_{;} 3.209 \mathrm{E}$ & $638-592$ & & & 0.535 & \\
\hline 17 May 02 & $36.590 \mathrm{~N} ; 2.817 \mathrm{E}$ & $178-181$ & 102.463 & & & \\
\hline 17 May 02 & $36.635 \mathrm{~N} ; 2.789 \mathrm{E}$ & $59-59$ & & & & \\
\hline 17 May 02 & $36.653 \mathrm{~N} ; 2.659 \mathrm{E}$ & $47-49$ & & & & \\
\hline 17 May 02 & $36.692 \mathrm{~N}_{;} 2.556 \mathrm{E}$ & $137-141$ & 1.706 & & & \\
\hline
\end{tabular}

relation of dimension 1 with mean weight of prey (r: 0.750, p < 0.019); dimension 2 was correlated with PP4 (r: $-0.700, \mathrm{p}<0.035)$.

\section{Plesionika gigliolii}

This species showed lower trophic diversity indexes (Table 3). It preyed on euphausiids (Euphausia hemigibba and Meganyctiphanes norvegica), mysids, hyperiids, insect remains, mesopelagic fish (Benthosema glaciale and Notoscopelus elongatus) and also consumed planktonic foraminiferans. The most important prey for this species were mesopelagic fish $(>30 \%$ of the weight of diet composition), mysids ( $>20 \%$ in number) and euphausiids (Meganyctiphanes norvegica) (Fig. 1). Hyperiids were a secondary food source.

\section{Plesionika edwardsii}

This species was found to prey on euphausiids, polychaetes and mesopelagic fish (Notoscopelus elongatus and Stomiiformes). Sand, bivalves and gastropod remains were also found. Nylon threads were found in $50 \%$ of foreguts.

\section{Plesionika martia}

The diet of Plesionika martia seemed to be less diversified than that of $P$. heterocarpus (Table 3). It preyed on mesopelagic decapods (Pasiphaea spp., Sergia robusta and Sergestes arcticus), polychaetes (mainly Glycera sp.), euphausiids, hyperiids (Phrosina semilunata, Phronima sedentaria and Vibilia armata) and mesopelagic fish (Myctophidae and Stomiiformes, mainly Cyclothone braueri). In terms of weight, number and occurrence (Fig. 1), the most important prey were mesopelagic decapods, hyperiids (Phrosina semilunata) and mesopelagic fish (mainly Benthosema glaciale and Stomiiformes). Euphausiids (Meganyctiphanes norvegica) were dominant in a small percentage of foreguts.

MDS analysis of the diet composition for Plesionika martia separated groups of samples mainly as a function of latitude (Fig. 2) giving a stress of 0.166. Hauls L16, L17, L18 and L19 were grouped in the right part of Axis (dimension) 1, and hauls L13, L14, L15 and L23 on the left. The samples on the right all pertained to the same area. No other trends were observed. However, no other latitudinal groups were observed and latitude was not correlated with either of the 2 dimensions of MDS (see below). 
Table 2. Composition of the diet of Plesionika species. 1: P. edwardsii; 2: P. gigliolii; 3: P. heterocarpus; 4: P. martia. *Taxa used for statistical analysis

\begin{tabular}{|c|c|c|c|}
\hline Prey & Predator & Prey & Predator \\
\hline PORIFERA* & 1 & Apseudes spinosus* & 3,4 \\
\hline Pachastrellidae & 3 & Apseudes sp. & 1,3 \\
\hline Hyalonema thomsoni & 3 & Copepoda & \\
\hline CNIDARIA $^{*}$ & & Harpacticoidea & 3 \\
\hline Hydrozoa & 4 & Calanoidea & 3 \\
\hline POLYCHAETA & & Unidentified ${ }^{*}$ & 3 \\
\hline Errantia & & INSECTA & \\
\hline Aphroditidae* & 3 & Diptera* & 2,3 \\
\hline Glycera sp.* & $2,3,4$ & MOLLUSCA & \\
\hline Eunicidae $^{*}$ & 3 & Bivalvia & \\
\hline Eunice dubitatus & 3 & Lucinidae & 3 \\
\hline Nephthys sp. & 4 & Chlamys sp. & 3 \\
\hline Unidentified ${ }^{*}$ & $1,2,3$ & Unidentified Bivalvia* & 3 \\
\hline ARTHROPODA & & Gastropoda & \\
\hline CRUSTACEA & & Benthonella & 3 \\
\hline Decapoda & & Turritella sp. & 1 \\
\hline Natantia* $^{*}$ & 4 & Rissoa sp. & 3 \\
\hline Pasiphaea sp.* & 2,4 & Margarites cinereus & 3 \\
\hline Sergestidae* & 4 & Pyramidellidae (Odostomia) & 3 \\
\hline Sergia robusta* & 4 & Unidentified Gastropoda & \\
\hline Sergestes arcticus* & 4 & Cephalopoda & \\
\hline Acanthephyra sp & 3 & Teuthoidea & 3 \\
\hline Unidentified* ${ }^{*}$ & 3,4 & Sepiolidae* & 3,4 \\
\hline Brachyura & 2,3 & Unidentified Cephalopoda* & 1,3 \\
\hline Unidentified Crustacea & $1,2,3$ & ECHINODERMATA & \\
\hline Euphausiacea* ${ }^{*}$ & $1,2,3,4$ & Echinoidea* ${ }^{*}$ & 3,4 \\
\hline Euphasia hemihibba* & 3 & Ophiuroidea & \\
\hline Euphasia kronii & 3 & Holothuroidea & \\
\hline Euphasia sp. & 3 & Cucumaria sp. & 2,3 \\
\hline Nicthiphanes couchii & 3 & Lapidoplax sp. & 3 \\
\hline Nematoscelis megalops & 4 & CHAETOGNATA* ${ }^{*}$ & 2,3 \\
\hline Meganyctiphanes norvegica* & $2,3,4$ & OSTEICHTHYES & \\
\hline Mysidacea $^{*}$ & & Mesopelagic fish* ${ }^{*}$ & $1,2,3,4$ \\
\hline Boreomysis sp. & 3 & Benthic fish ${ }^{*}$ & $1,3,4$ \\
\hline Siriella sp. ${ }^{*}$ & 3 & Cyclothone braueri* & 4 \\
\hline Leptomysis sp. ${ }^{*}$ & 3 & Myctophidae* & 3,4 \\
\hline Unidentified Mysidacea & 3 & Benthosema glaciale* & $2,3,4$ \\
\hline Amphipoda* ${ }^{*}$ & 2 & Hygophum sp. & 3,4 \\
\hline Gammaridea & 3 & Notoscopelus elongatus & 1,2 \\
\hline Hyeridea $^{*}$ & $1,2,3$ & Diaphus sp. & 4 \\
\hline Euthemisto sp. & 4 & Stomiiformes* & $1,2,4$ \\
\hline Phrosina semilunata* & $2,3,4$ & Macrouridae & 3 \\
\hline Phronima sedentaria* & $2,3,4$ & Belonidae & 3 \\
\hline Vibilia armata & 3,4 & Unidentified $^{*}$ & \\
\hline Isopoda & & FORAMINIFERA* ${ }^{*}$ & 2,3 \\
\hline Cirolana sp.* & 3,4 & Globigerina & 2,3 \\
\hline Gnathia sp. & 2,3 & Elphidium sp. & 3 \\
\hline Other Flabellifera & 3 & Bolivina sp. & 3 \\
\hline Unidentified & & Quinqueloculina sp. & 2,3 \\
\hline Tanaidacea & & Vegetal rests & 2 \\
\hline Apseudidae* & 2,3 & Detritus & 1,3 \\
\hline
\end{tabular}

The diet of Plesionika martia was quite different among the 2 groups. In the first, hyperiids (i.e. Phrosina semilunata) were dominant in the diet with myctophids (i.e. Benthosema glaciale and Hygophum sp.) and Cyclothone braueri. In the second group, the dominant prey were euphausiids (i.e. Meganycthiphanes norvegica), polychaetes, decapods (i.e. Pasiphaea spp. and Sergestidae) and Stomiiformes.

Correlations with the projections of samples in dimensions 1 and 2 ( $\mathrm{n}=9$ ) showed that Dimension 1 significantly correlated (non-parametric Spearman correlation) with PP1 (Spearman $\mathrm{r}:-0.800, \mathrm{p}<10^{-3}$ ), PP4 (r: 0.920, $\left.\mathrm{p}<10^{-4}\right)$, biomass ( $\mathrm{r}:-0.733, \mathrm{p}=$ $0.024)$, abundance ( $\mathrm{r}:-0.783, \mathrm{p}=$ 0.012), Decapoda Natantia (r: $\left.-0.858, \mathrm{p}<10^{-3}\right)$, Calanoidea (r: $\left.-0.861, \mathrm{p}<10^{-3}\right)$, suprabenthos (r: $-0.796, p=0.010)$ and mean weight of prey (r: 0.783, $\mathrm{p}=$ 0.012). A significant correlation with the projection of samples in Dimension 2 was found with $\mathrm{PP}_{\text {sim }}(\mathrm{r}:-0.744, \mathrm{p}<0.021)$, trophic diversity (r: $-0.733, \mathrm{p}<$ 0.024 ) and the percentage of mature females (r: 0.736, p < 0.023).

\section{Overall Plesionika spp. analysis}

The global results of the percentage of empty stomachs ranged from 0 to $12 \%$ for Plesionika heterocarpus, and was $48 \%$ for P. edwardsii, between 17 and $33 \%$ for $P$. gigliolii and between 25 and $55 \%$ for P. martia. There-
Table 3. Trophic diversity indexes in the diet of Plesionika spp.

\begin{tabular}{|lccccc|}
\hline Species & $S$ & $N$ & $d$ & $J^{\prime}$ & $H^{\prime}$ \\
\hline$P$. edwardsii & 10 & 10 & 3.909 & 1 & 2.303 \\
P. gigliolii & 26 & 26 & 7.673 & 1 & 3.258 \\
$P$. heterocarpus & 62 & 62 & 14.78 & 1 & 4.127 \\
$P$. martia & 28 & 28 & 8.103 & 1 & 3.332 \\
\hline
\end{tabular}

fore, the overall feeding intensity between species decreased with depth. The trends within species for fullness (Fig. 3) were increased fullness for P. heterocarpus in an eastward direction and increased fullness for P. martia at its shallower depth-range distribution. Few hauls were available to obtain any pattern for $P$. gigliolii. However, $73 \%$ of $P$. gigliolii specimens with empty stomachs were females with well-developed 

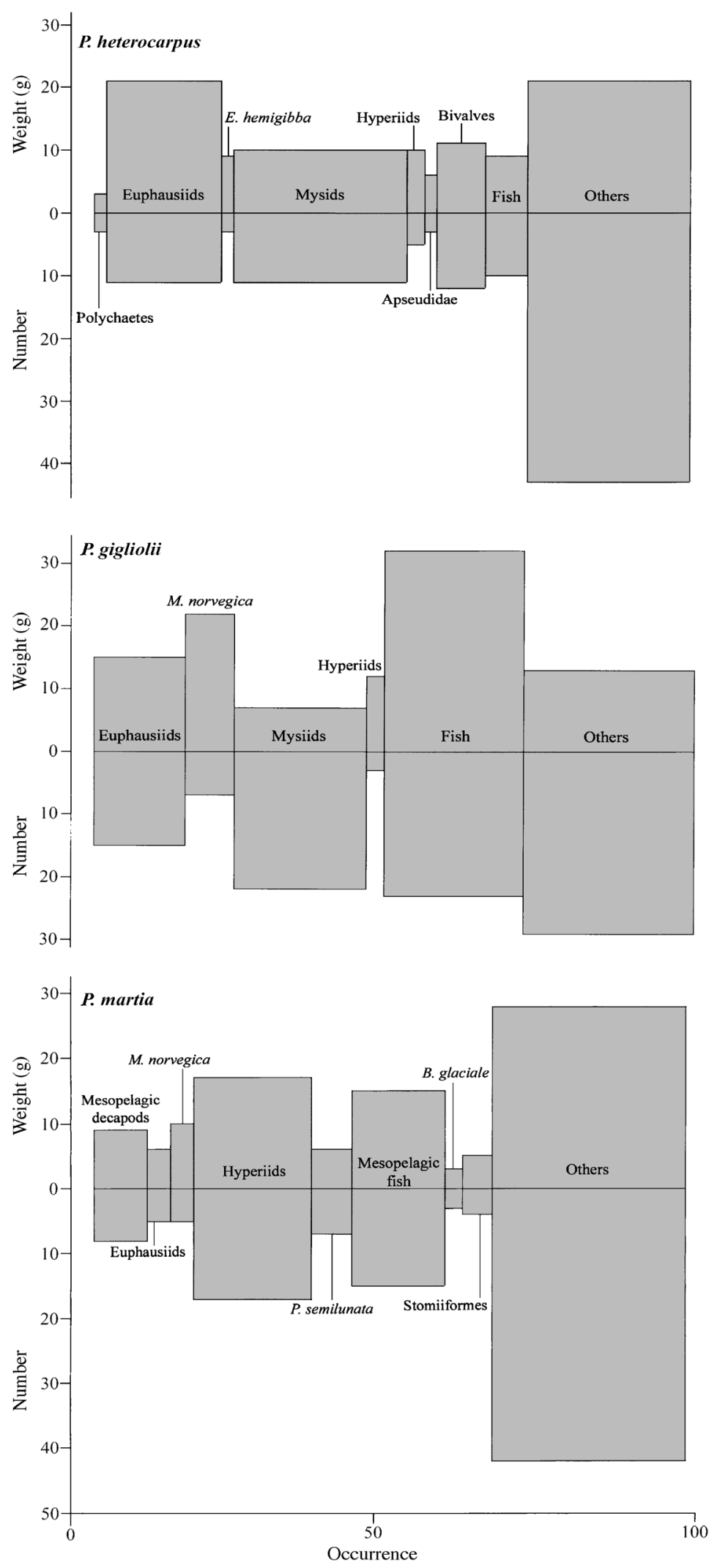

Fig. 1. Frequency of occurrence of prey combined with weight and number for (a) Plesionika heterocarpus, (b) P. gigliolii and (c) P. martia green gonads (13\% ovigerous). P. martia showed less developed gonads in comparison to $P$. gigliolii and in this species, $13 \%$ of specimens with empty stomachs were females (23\% ovigerous).

A significant correlation was found between fullness by haul and depth (Spearman r: -0.569 , $\left.\mathrm{p}<10^{-3}\right)$, hour (r: $\left.-0.442, \mathrm{p}<0.034\right), \mathrm{PP}_{\text {sim }}$ ( $\mathrm{r}$ : 0.462, p $<0.026$ ), PP1 (r: 0.461, p < 0.027), PP6 (r: 0.417, p < 0.048), density of Plesionika spp. (r: $0.541, \mathrm{p}<10^{-3}$ ), mean weight of Plesionika spp. (r: $-0.477, \mathrm{p}<0.021$ ) and mean weight of prey (r: $-0.450, \mathrm{p}<0.030)$.

Cluster analysis (Fig. 4) of the diet composition for all the species showed the segregation of several groups of samples: the first was represented by Plesionika martia samples, except in haul L7. The second group was formed by 2 subgroups: one formed only by $P$. heterocarpus samples and the other by $P$. gigliolii, $P$. edwardsi and P. martia (Haul 7) samples. P. heterocarpus and $P$. gigliolii co-occurred in 2 hauls (L5 and L6) but they were separated into 2 distinct sub-groups. On the other hand, haul L22 of $P$. edwardsi and of $P$. gigliolii segregated into the same sub-group. MDS analysis segregated groups of samples mainly as a function of depth giving a stress of 0.215 . All P. martia samples are grouped in the left part of Axis (dimension) 1 and $P$. heterocarpus samples in the lower part of the right side. $P$. gigliolii and $P$. edwardsi samples are grouped in the upper part (Fig. 4).

Correlations with the projections of samples in dimensions 1 and $2(n=23)$ showed that D1 significantly correlated (non-parametric Spearman) with depth ( $\mathrm{r}$ : $-0.803, \mathrm{p}<10^{-6}$ ), $\mathrm{PP}_{\text {sim }}$ $\left(\mathrm{r}:-0.803, \mathrm{p}<10^{-6}\right)$, PP1 (r: $\left.-0.803, \mathrm{p}<10^{-6}\right)$, PP6 (r: $-0.803, \mathrm{p}<10^{-6}$ ), abundance (r: -0.803 , $\mathrm{p}<10^{-6}$ ), Calanoidea ( $\mathrm{r}:-0.803, \mathrm{p}<10^{-6}$ ), trophic diversity $\left(\mathrm{r}:-0.803, \mathrm{p}<10^{-6}\right)$, density of Plesionika spp. ( $\mathrm{N}$ of ind. $\mathrm{km}^{-2}$ of the species) ( $\mathrm{r}:-0.803, \mathrm{p}<10^{-6}$ ), mean weight of Plesionika spp. (r: $\left.-0.803, \mathrm{p}<10^{-6}\right)$ and mean weight of prey $\left(\mathrm{r}:-0.803, \mathrm{p}<10^{-6}\right)$.

A significant correlation with the projection of samples in D2 was found with PP4 (r: -0.495, p < 0.016), Decapoda Natantia ( $\mathrm{r}$ : 0.645, p < 10 ${ }^{-4}$ ) and suprabenthos abundance (r: 0.724, p < 10 ${ }^{-5}$ ).

Two MLR fullness models were obtained for the Plesionika spp. diet (Table 4). In model $\mathrm{MLR}_{1}(1)$, fullness is significantly correlated with hour, PP4, latitude and PP6. The fitted equation (Table 4) showed that this model explains $80.3 \%$ of the variability of log fullness. In model $\mathrm{MLR}_{2}$ (2), fullness was significantly correlated with latitude, PP4 and depth, but the goodness-of-fit 
decreased to $R^{2}=0.674$. The tolerance, which indicates the existing correlation between pairs of independent variables, was between 0.912 and 0.112 in $\mathrm{MLR}_{1}$, and

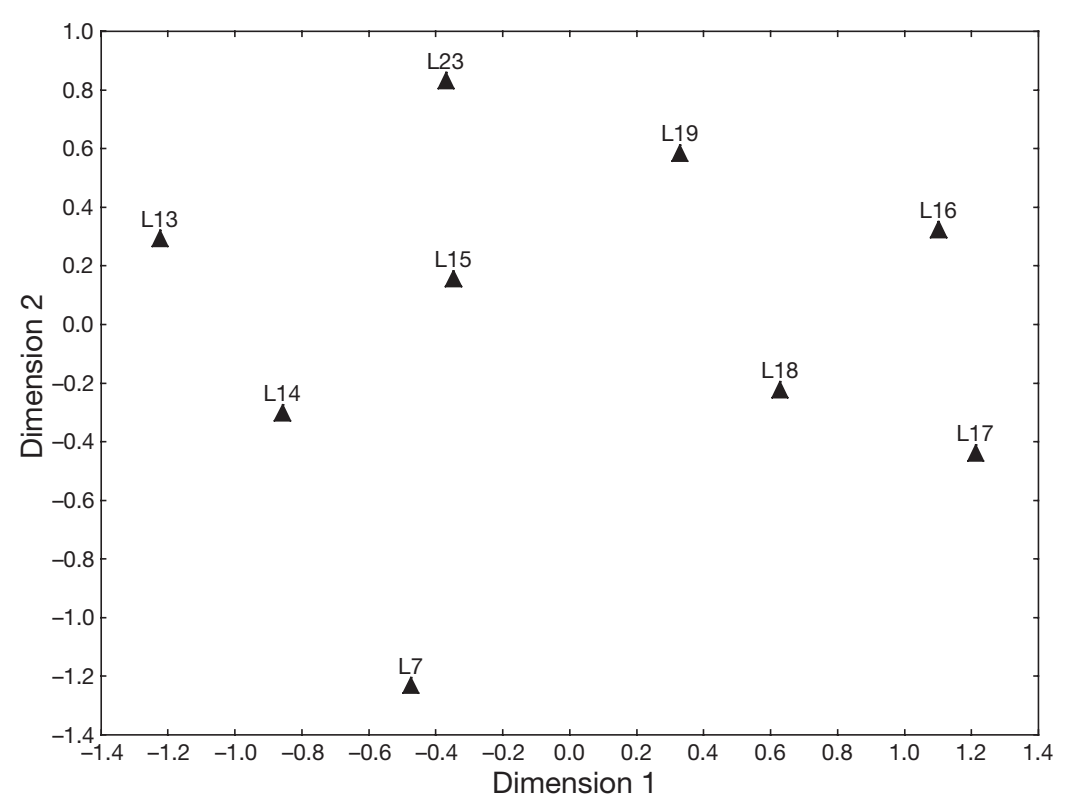

Fig. 2. Aggregation of foregut content samples for Plesionika martia and Multidimensional Scaling, MDS. Designations are haul numbers

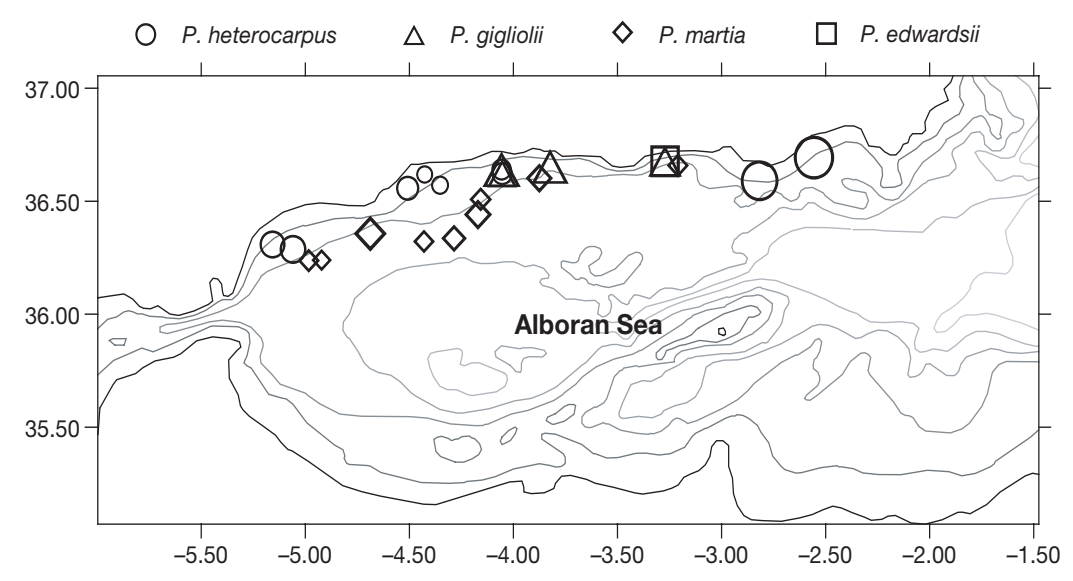

Fig. 3. Fullness mapped in the study area (Alboran Sea) for the 4 species. Symbol size represents degree of fullness between 0.889 and 0.719 in $\mathrm{MLR}_{2}$. The relationship between fullness and the above mentioned parameters is better expressed by $\mathrm{MLR}_{2}$ as higher values of tolerance (less redundancy, meaning low correlation between variables) were observed.

Trophic diversity in Plesionika heterocarpus was relatively high (Table 3); in P. martia and $P$. gigliolii trophic diversity was intermediate, while in P. edwardsii it was low due to the few hauls available.

\section{Prey-predator size relationships}

Correlations between Plesionika spp. size $(C L, \mathrm{~mm})$ and prey size (Fig. 5) were positive, both for fish $\left(\mathrm{R}^{2}=0.437\right)$ and for euphausiids $\left(\mathrm{R}^{2}=0.440\right)$. Fish prey was mainly comprised of Benthosema glaciale and secondarily of Hygophum spp. and Notoscopelus elongatus. Euphausiid species, for which mandibles were measured, included Euphausia hemigibba and Meganyctiphanes norvegica. There was a positive correlation between the hour of sampling and the occurrence of euphausiids in guts. Correlations between the hour of sampling and fullness were negative for P. martia (higher fullness at the beginning of the cycle: morning) and positive for $P$. heterocarpus.

\section{DISCUSSION}

Plesionika species appear to prefer similar prey in different areas along their wide geographical range. They can be considered as a trophic guild of 'macroplankton-epibenthic feeders' (Cartes 1998) or 'non migratory macroplankton feeders' (Cartes et al. 2002). This guild includes species whose diets are mainly based on pelagic resources, captured in the Benthic Boundary Layer, and located a few meters above the bottom (Wishner 1980, Hargreaves 1984, Angel 1990). Deep bathyal

Table 4. Characteristics of the multiple linear regression (MLR) models constructed to predict fullness. Hour of sampling $(H)$, latitude (Lat), Primary production 4 wk before sampling (PP4), Primary production 6 wk before sampling (PP6) and depth (D) were the considered independent variables; $\mathrm{p} \leq 0.05$ for all the independent variables. DIM1: dimension 1 from MDS analysis

\begin{tabular}{|c|c|c|c|}
\hline Model & $n$ & $\mathrm{r}^{2}$ & $\mathrm{p}$ \\
\hline (1) $\log$ fullness $=-210.468-0.697 \log H-1.114 \log \mathrm{PP} 4+133.825 \log L a t-3.146 \log \mathrm{PP} 6$ & 25 & 0.803 & $<10^{-5}$ \\
\hline (2) $\log$ fullness $=-68.359+44.578 \log L a t-1.945 \log$ PP4 $-0.219 \log D$ & 25 & 0.674 & $<10^{-4}$ \\
\hline $\log D I M 1=-3.397+1.999 \log D$ & 25 & 0.608 & $<10^{-4}$ \\
\hline
\end{tabular}



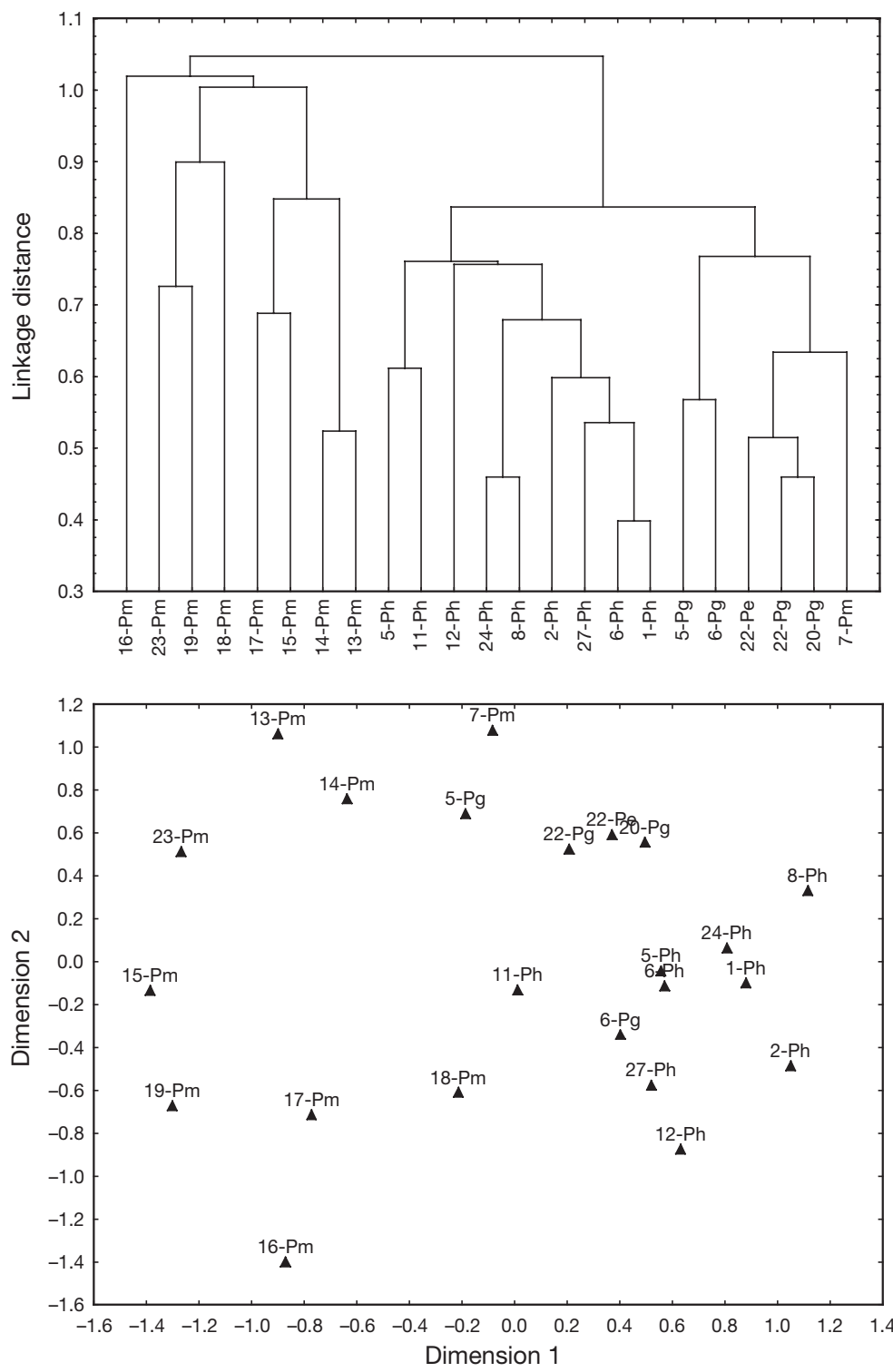

Fig. 4. Aggregation of foregut content samples for all the species of Plesionika and MDS. Codes: 13-Pm means Haul 13, P. martia, etc.

species dwelling on the middle-slope assemblage (below ca. 350 m) (Abelló et al. 1988, Cartes et al. 1994) clearly fit within this guild. P. martia, therefore, preyed mostly on mesopelagic decapods, hyperiids and mesopelagic fish in the Alboran Sea. On the NW African Slope and in the Catalan Sea, P. martia was found to prey mainly or exclusively on euphausiids (Meganycthiphanes norvegica) and mesopelagic decapods (Pasiphaea sivado) (Lagardère 1972, Cartes 1993a, 1993b). In the Bay of Biscay, however, this species has been suggested to be a scavenger (Lagardère 1977). $P$. edwardsii also seemed to prey mostly on mesopelagic species ( $M$. norvegica, P. sivado and Boreomysis arctica), as observed in the Catalan Sea (Cartes 1993a,b). In the same way, the most important prey for $P$. gigliolii were mesopelagic species (myctophid fish, mysids, euphausiids and hyperiids), though at a qualitative level some benthic prey (polychaetes, foraminiferans, echinoderms) were also frequently ingested in the Sardinian channel (Mura 1995). Although some of these species also exhibit periods of benthic feeding activity, in which they prey on slow-moving organisms such as crustaceans and fish remains (Cartes 1998), benthic prey are always secondary in their diet.

In contrast, Plesionika heterocarpus, the shallowest species, is the only species whose diet is increasingly and even mainly based on benthic organisms, both in the Bay of Biscay, where $P$. heterocarpus mostly preys on polychaetes (Lagardère 1977) and in the South Aegean Sea where molluscs, decapods and polychaetes dominate its diet (Labropoulou \& Kostikas 1999). Benthos is also important in the diet of $P$. heterocarpus in the Alboran Sea, compared with its contribution to the diet of the rest of Plesionika species. In fact, benthos resources should have greater importance as a food-source in shelf communities, which agrees with a generally recognized decrease in benthos biomass with depth (Rowe 1983). Higher diversification of benthic prey inhabiting the continental shelf, in comparison to pelagic prey consumed on the slope by pandalids, may also explain the higher dietary diversity in $P$. heterocarpus compared to species of the deeper, mesopelagic feeders, P. martia and $P$. gigliolii. From an energetic point of view, the decrease in benthic biomass with depth may tend towards a strategy of caloric maximization by benthopelagic consumers preying on highly energetic mesopelagic organisms (T. Madurell \& J. E. Cartes unpubl.). This trend was suggested on mid-slope depths in the Ionian Sea, an oligotrophic area where densities of benthos are low.

Decapod crustaceans generally occupy a lower trophic level than fish, also in the deep-sea domain (e.g. Polunin et al. 2001). Decapods, therefore, have been rather considered as scavengers or detritivorous (Gage \& Tyler 1992). Some detailed studies point, however, to active predation by decapods on hyperiids and Cirolanidae (e.g. by Plesionika martia) as shown by the occurrence of whole remains of these taxa in guts. Prey size selection constituted further evidence of hunting activity: maximum otolith length (mainly of Benthosema glaciale) increased with predator size and the same pattern was observed for euphausiid mandibles (Meganyctiphanes norvegica and Euphausia hemigibba). As shrimp size increased, there was a pronounced shift 


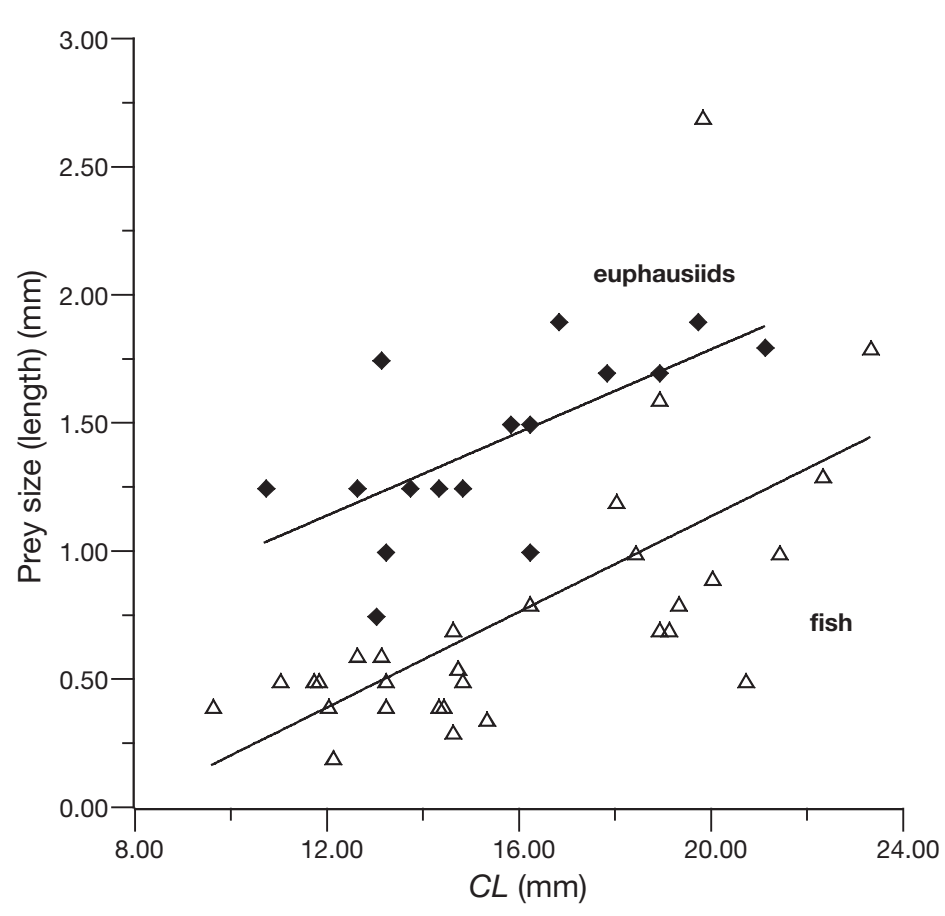

Fig. 5. Relationship between prey-size (mandible height for euphausiids and otolith length for fish, $\mathrm{mm}$ ) and predator-size $(C L, \mathrm{~mm})$

towards larger prey: $P$. martia mainly prey on $M$. norvegica, while the smaller $P$. heterocarpus mostly on E. hemigibba. Until now, this kind of prey-predator size relationships have only been evidenced for fish (Macpherson 1978), which ingest entire prey.

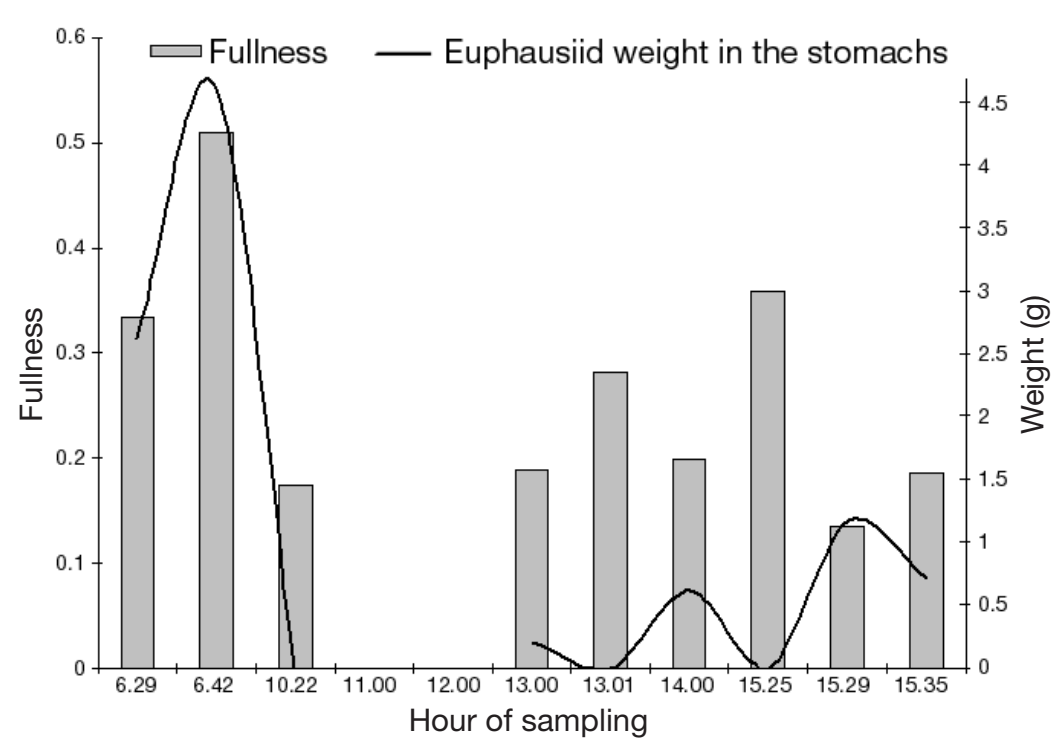

Fig. 6. Plesionika martia. Relationship between hour of sampling, fullness and euphausiid weight (in g) in the foregut content
Active predation by decapods might be related to the occurrence of significant changes in the daily feeding activity of species. Some pandalids (e.g. Plesionika martia) exhibit predation on Pasiphaea spp. restricted to the early hours of day-light (Cartes 1993c). In the Alboran Sea, foregut fullness of $P$. martia was higher at dawn (from 06:00 to 08:00 h) related to predation on mesopelagic species (euphausiids in this case) (Fig. 6). Diel vertical migrations of mesopelagic fauna (Franqueville 1971, Merrett \& Roe 1974, Omori 1974, Roe 1974, 1983, Hargreaves 1984) comprising mesopelagic prey species such as Pasiphaea spp., Sergestes arcticus, fish and euphausiids (Cartes 1993a) seemed to be important in influencing feeding activity rhythms in the deep sea decapods. In contrast, the rather epibenthic feeder $P$. heterocarpus displayed an opposite pattern of feeding activity (higher fullness between 11:00 and 14:00 h).

Scavenging is concluded to be a secondary activity in the feeding habits of pandalids: insect remains (e.g. Diptera), probably transported by bottom drifts, were also found in the Alboran Sea samples in Plesionika heterocarpus and even in P. gigliolii at depths of $272 \mathrm{~m}$. In all the species, osteichthyes remains consisted of large scales, which were probably ingested in the water column (Hopkins \& Baird 1975, Cartes 1993a).

Feeding intensity is positively related to the degree and index of fullness and negatively related to the percentage of empty stomachs (Bowman \& Bowman 1980). The low values of vacuity index indicate that feeding intensity is high for Plesionika heterocarpus and decreases for deeper bathyal species, particularly for the deepest-dwelling species, P. martia. The high proportion of empty stomachs in decapod species that inhabit deep slope zones has been previously reported (Wenner 1979, Cartes \& Abelló 1992, Cartes 1993b) and seems to be a general pattern for such species as an adaptation to the deep sea environment, where trophic resources are scarce. In general, size did not affect the feeding intensity of the species examined, while the sexual state did, with higher vacuity among mature females of $P$. gigliolii with large well-developed green gonads. Among decapod crustaceans, this last aspect has only previously been documented for Liocarcinus depurator (Freire 1996), although it has been widely reported for fish (e.g. Velasco \& Olaso 1998, Dia et al. 2000, Morte et al. 2001).

Most Pandalidae prey on pelagic macroplankton species, particularly on the slope. Therefore, some aspects of the biology of these species (e.g. recruitment, swarms to spawn) may probably be coupled with blooms of plankton and ultimately with peaks of pri- 
mary production. In the pelagic domain, a delay between peaks of phytoplankton blooms and krill was suggested by different authors in the North Sea (Noji 1991, Dam et al. 1993). Krill concentration may be the result of oceanographic features coupled with favorable feeding conditions. The shear zones and the sluggish currents caused by topographical features (i.e. shelf break) may provide suitable sites that retain krill swarms (Ichii et al. 1998). The response to these signals at bathyal depths probably occurs by fluxes of particulate organic matter (detritus) throughout the water column (Miquel et al. 1994) and after a transport of organic matter explained by organism migration (e.g. Ribera Maycas 1997). The Alboran Sea is probably too complicated an ecosystem in which to evidence a possible coupling between phytoplankton pigment concentration (as a measure of primary production), zooplankton and benthopelagic shrimp densities, due to the complex circulation patterns with anticyclonic gyres (Parrilla et al. 1986, Heburn \& La Violette 1990) and local upwelling processes (see seawifs.gsfc.nasa. gov for maps of PP). Furthermore, Plesionika species abundance is expected to be more related to peaks of primary production among benthopelagic feeders (e.g. P. martia) than among benthic feeders (e.g. P. heterocarpus). In fact, abundance only followed this pattern (positive significant correlation with a delay of 1 mo, PP4) for P. martia (Fig. 7). Maps derived from satellites showed that PP recorded simultaneously to the sampling survey was concentrated close to the coasts (upwelling processes), while 1 mo before, maxi-

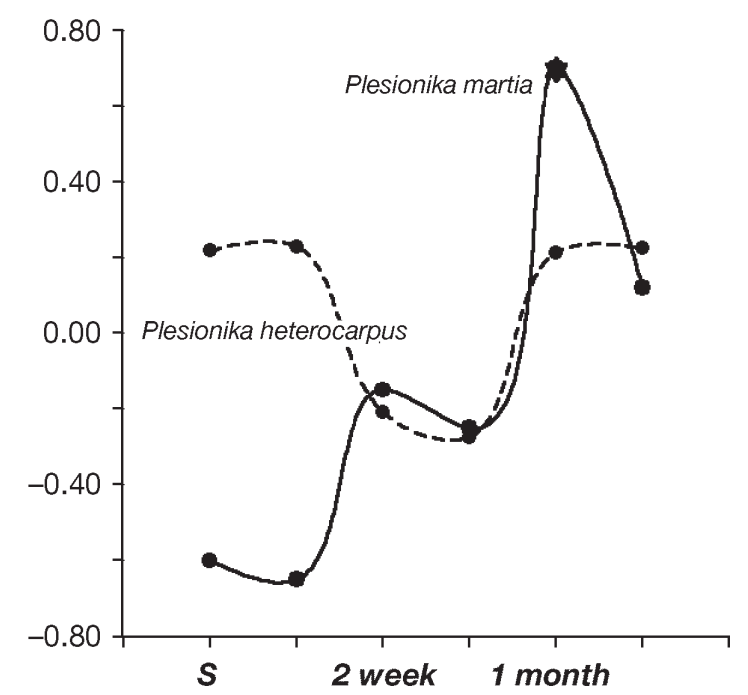

Fig. 7. Significance (r) of the relationship between Plesionika martia and $P$. heterocarpus abundance and pigment phytoplankton concentration (as a measure of primary production PP) recorded in at different times before and during the sampling survey mum values were evidenced in the open sea. This seems to be related to the deeper distribution of P. martia.

In the deep Mediterranean, water masses usually have a constant temperature of $13.5^{\circ} \mathrm{C}$ at depths below 200 m (Hopkins 1985). This could explain why physical oceanographic features (e.g. temperature) correlated neither with the fullness nor with the diet of Plesionika spp. Stomach fullness was also correlated to PP 1 mo previously in the case of the hake $M$. merluccius along the Iberian coasts (Cartes et al. 2004). Among Plesionika spp., we observed a significant correlation between fullness of $P$. heterocarpus and PP4, while no significant correlation was detected for P. martia.

Our results indicate that stomach fullness generally increased with increasing density in Plesionika spp., suggesting feeding aggregations. Possible causes of these aggregations could be related, in the case of $P$. martia, to reproductive processes, rather than to feeding, because a peak of mature females was evidenced for this shrimp in May-June in the Tyrrhenian (Fanelli \& Belluscio 2003) and Sardinian Seas (Campisi et al. 1998). P. heterocarpus, in contrast, shows a more continuous reproductive cycle (Company \& Sardà 1997). In our data, P. martia populations were mainly composed of adult specimens (mean $C L=20 \pm 4.9 \mathrm{~mm}$ ) while both juveniles and adults were abundant among $P$. heterocarpus populations (mean $C L=12 \pm 2.9 \mathrm{~mm}$ ). Finally, further similar considerations for diet do not seem to be as easy to establish as for fullness because diet is a multidimensional variable, depending on several factors. In both dominant Plesionika species, however, MDS dimensions were also correlated with PP4 and further significant correlations with other PP data (from $\mathrm{PP}_{\text {sim }}$ to PP6) were also found.

Acknowledgements. The authors thank all the participants of the MEDITS cruise, especially P. Abelló and L. Gil de Sola. We also wish to thank T. Lombarte for helping us in myctophid otolith identification.

\section{LITERATURE CITED}

Abelló P, Valladares FJ, Castellon A (1988) Analysis of the structure of decapod crustacean assemblage off the Catalan coast (North-Western Mediterranean). Mar Biol 98: $39-49$

Angel MV (1990) Life in the benthic boundary layer: connections to the mid-water and sea floor. Phil Trans R Soc Lond 331:15-28

Bertrand JA, Gil De Sola L, Papaconstantinou C, Relini G, Souplet A (2000) An international bottom trawl survey in the Mediterranean: the Medits program. IFREMER Actes Colloq 26:76-93

Bowman RE, Bowman EW (1980) Diurnal variation in the feeding intensity and catchability of silver hake (Merluccius bilinearis). Can J Fish Aquat Sci 37:1565-1572 
Campisi S, Cuccu D, Murenu M, Follesa MC, Cau A (1998) Aspetti riproduttivi di Plesionika martia (A. Milne Edwards, 1883) nei mari sardi. Biol Mar Medit 5(2):268-272

Carbonell A, Abelló P (1998) Distribution characteristics of pandalid shrimps (Decapoda: Caridea: Pandalidae) along the Western Mediterranean Sea. J Nat Hist 32: 1463-1474

Cartes JE (1993a) Diets of deep-water pandalid shrimps on the western Mediterranean slope. Mar Ecol Prog Ser 96: $49-61$

Cartes JE (1993b) Diets of deep-sea brachyuran crabs in the western Mediterranean Sea. Mar Biol 117:459-468

Cartes JE (1993c) Day-night feeding by decapod crustaceans in a deep-water bottom community in the western Mediterranean Sea. J Mar Biol Ass UK 73:795-811

Cartes JE (1994) Influence of depth and season on the diet of the deep-water aristeid Aristeus antennatus along the continental slope ( 400 to $2300 \mathrm{~m}$ ) in the Catalan Sea (western Mediterranean) Mar Biol 120(4):639-648

Cartes JE (1998) Feeding strategies and partition of food resources in deep-water decapod crustaceans in relation to depth (between 400-2300). J Mar Biol Ass UK 78: 509-524

Cartes JE, Abelló P (1992) Comparative feeding habits of polychelid lobsters in the western Mediterranean. Mar Ecol Prog Ser 84:139-159

Cartes JE, Maynou F (1998) Food consumption by bathyal decapod crustacean assemblages in the western Mediterranean: predatory impact of megafauna and the food consumption-food supply balance in a deep-water food web. Mar Ecol Prog Ser 171:233-246

Cartes JE, Sardà F, Company JB, Lleonart J (1993) Day-night migrations by deep-sea decapod crustaceans in experimental samplings in the Western Mediterranean Sea. J Exp Mar Biol Ecol 171(1):63-73

Cartes JE, Company JB, Maynou F (1994) Deep-water decapod crustacean communities in the northwestern Mediterranean: Influence of submarine canyons and season. Mar Biol 120(2):221-229

Cartes JE, Abelló P, Lloris D, Carbonell A, Torres P, Maynou F, Gil De Sola L (2002) Feeding guilds of western Mediterranean demersal fish and crustaceans: an analysis based on a spring survey. Sci Mar 66(Suppl 2):209-220

Cartes JE, Rey J, Lloris D, Gil de Sola L (2004) Influence of environmental variables on the feeding and diet of European hake (Merluccius merluccius) on the Mediterranean Iberian coasts. J Mar Biol Assoc UK 84:831-835

Company JB, Sardà F (1997) Reproductive patterns and population characterics in 5 deep-water pandalid shrimps in the Western Mediterranean along a depth gradient (150-1100 m). Mar Ecol Prog Ser 143:49-58

Crosnier A, Forest J (1973) Les crevettes profondes de l'Atlantique oriental tropical. Faune Trop 19:1-409

Dam HG, Miller CA, Jonasdottir SH (1993) The trophic role of mesozooplankton at $47^{\circ} \mathrm{N}, 20^{\circ} \mathrm{W}$ during the North Atlantic Bloom Experiment. Deep Sea Res II 40:197-212

Dia M, Ghorbel M, Bouain A, Kone Y (2000) Regime alimentaire de Pagrus caeruleostictus (Sparidae) des cotes de Nouakchott (Mauritanie). Cybium 1:81-88

Fanelli E, Belluscio A (2003) Some aspects of reproductive biology of pandalid shrimps of the genus Plesionika (Bate, 1888) (Crustacea, Decapoda) in the central Tyrrhenian sea. Biol Mar Medit 10(2):808-813

Franqueville C (1971) Macroplancton profond (Invertébrés) de la Méditerranée nord-occidentale. Tethys 3(1):11-56

Freire J (1996) Feeding ecology of Liocarcinus depurator (Decapoda: Portunidae) in the Ria de Arousa (Galicia, north-west Spain): effects of habitat, season and life history. Mar Biol 126:297-311

Gage JD, Tyler PA (eds) (1992) Deep-sea biology: a natural history of organisms at the deep-sea floor. Cambridge University Press, Cambridge

Hargreaves PM (1984) The distribution of Decapoda (Crustacea) in the open ocean and near bottom over an adjacent slope in the northern North-east Atlantic ocean during Autumn 1979. J Mar Biol Assoc UK 64:829-857

Heburn GW, La Violette PE (1990) Variations in the structure of the anticyclonic gyres found in the Alboran Sea. J Geophys Res 95(C2):1599-1613

Hopkins TL, Baird RC (1975) Net feeding in mesopelagic fishes. Fish Bull US 73:908-914

Hopkins TS (1985) Physics of the sea. In: Margalef R (ed) Key environments: Western Mediterranean. Pergamon Press, Oxford, p 100-125

Hyslop EJ (1980) Stomach contents analysis: a review of methods and their application. J Fish Biol 17:411-429

Ichii T, Katayama K, Obitsu N, Ishii H, Naganobu M (1998) Occurrence of Antarctic krill (Euphausia superba) concentrations in the vicinity of the South Shetland Islands: relationship to environmental parameters. Deep-Sea Res I 45(8):1235-1262

Jacob W, McClatchie S, Probert PK, Hurst RJ (1998) Demersal fish assemblages of southern New Zealand in relation to depth and temperature. Deep Sea Res I 45: $2119-2156$

Labropoulou M, Kostikas I (1999) Patterns resource use in deep-water decapods. Mar Ecol Prog Ser 184:171-182

Lagardère JP (1972) Recherches sur l'alimentation des crevettes bathypelagiques du talus Continentale de la Pente Continentale Marocaine. Tethys 3:655-675

Lagardère JP (1977) Recherches sur la distribution verticale et sur l'alimentation des crustaces decapodes benthiques de la Pente Continentale du Golfe de Gascogne. Analyse des groupements carcinologiques. Bull Cent Etud Rech Sci Biarritz 11(4):367-440

Macpherson E (1978) Regimen alimentario de Phycis blennoides (Bruenich) and Antonogadus megalokynodon (Kolombatovic) (Pisces: Gadidae) en el Mediterraneo occidental. Invest Pesq 42(2):455-466

Margalef R (1958) Information theory in ecology. Gen Syst 3: $36-71$

Maynou F, Cartes JE (2000) Community structure of bathyal decapod crustacean assemblages off the Balearic islands (south-western Mediterranean). J Mar Biol Assoc UK 80: 789-798

McClatchie S, Millar RB, Webster F, Lester PJ, Hurst R, Bagley N (1997) Demersal fish community diversity of New Zealand: is it related to depth, latitude and regional surface phytoplankton? Deep Sea Res I 44:647-667

Merret NR, Roe HSJ (1974) Patterns and selectivity in the feeding of certain mesopelagic fishes. Mar Biol 28: $115-126$

Miquel JC, Fowler SW, La Rosa J, Buat-Menard P (1994) Dynamics of the down-ward flux of particles and carbon in the open northwestern Mediterranean sea. Deep-Sea Research 41(2):243-261

Morte S, Redon MJ, Sanz-Brau A (2001) Diet of Scorpaena porcus and Scorpaena notata (Pisces: Scorpaenidae) in the western Mediterranean. Cah Biol Mar 42(4):333-344

Mura M (1995). Sulla biologia di Plesionika gigliolii (Senna, 1903) (Crustacea, Caridea, Pandalidae). Biol Mar Medit 2(2):245-249

Noji T (1991) The influence of macrozooplankton on vertical particulate flux. Sarsia 76:1-9 
Omori M (1974) The biology of pelagic shrimps in the ocean. Adv Mar Biol 12:233-324

Parrilla G, Kinder TH, Preller RH (1986) Deep and intermediate Mediterranean Water in the western Alboran Sea. Deep Sea Res 33(1):55-88

Pielou EC (1966) The measurement of diversity in different types of biological collections. J Theor Biol 13:131-144

Pielou EC (ed) (1984) In: Interpretation of ecological data: a primer on classification and ordination. John Wiley \& Sons, New York, p 263

Polunin NVC, Morales-Nin B, Pawsey WE, Cartes JE, Pinnegar JK, Moranta J (2001) Feeding relationships in Mediterranean bathyal assemblages elucidated by stable nitrogen and carbon isotope data. Mar Ecol Prog Ser 220:13-23

Ribera Maycas E (1997) Comportment migratoire et trophique des mysidaces benthopelagiqués Anchialina agilis et Haplostylus lobatus sur la marge continentale en Mediterranee Nord-Occidentale. Incidence sur les transferts de matiere. PhD thesis, Université de La Meditérranée, Marseille

Roe HSJ (1974) Observations on the diurnal vertical migrations of an oceanic animal community. Mar Biol 28:99-113

Roe HSJ (1983) Vertical distributions of euphausiids and fish

Editorial responsibility: Otto Kinne (Editor),

Oldendorf/Luhe, Germany in relation to light intensity in the Northwestern Atlantic. Mar Biol 77(3):287-298

Rowe GT (1983) Biomass and production of the deep-sea macrobenthos. In: Rowe GT (ed) Deep-sea biology: the sea, Vol 8. Wiley, New York, p 97-121

Shannon CE, Weaver W (1949) The mathematical theory of communication. Urbana University Press, p 122

Swynnerton GH, Worthington EB (1940) Note on the food of fish in Haweswater (Westmoreland). J Anim Ecol 9: 183-187

Velasco F, Olaso I (1998) European hake Merluccius merluccius (L., 1758) feeding in the Cantabrian Sea: seasonal, bathymetric and length variations. Fish Res 38(1):33-44

Wenner EL (1979) Some aspects of the biology of deep-sea lobsters of the family Polychelidae (Crustacea, Decapoda) from the western North Atlantic. Fish Bull US 77(2): 435-444

Wienberg R (1980) On the food and feeding habits of Pandalus borealis Kroyer 1838. Comm Meer int Coun Explor Sea C.M.-ICES/K: 9:1-25

Wishner KF (1980) The biomass of the deep-sea benthopelagic plankton. Deep Sea Res 27:203-216

Zariquiey Alvarez R (1968) Crustaceos Decapodos Ibericos. Inv Pesq 32:1-510

Submitted: November 4, 2003; Accepted: May 18, 2004

Proofs received from author(s): September 10, 2004 